\title{
Survey of the Health of Urban Residents: a Community-Driven Assessment of Conditions Salient to the Health of Historically Excluded Populations in the USA
}

\author{
Sirry Alang ${ }^{1}$ (iD $\cdot$ Cynthia Pando ${ }^{1,2} \cdot$ Malcolm McClain $^{1,3} \cdot$ Hasshan Batts $^{1,4} \cdot$ Abby Letcher $^{5,6} \cdot$ Janelle Hager $^{6}$. \\ Taylor Person ${ }^{4} \cdot$ Adama Shaw $^{1,7} \cdot$ Kwamaine Blake $^{4} \cdot$ Kevelis Matthews-Alvarado $^{1}$
}

Received: 3 July 2020 / Revised: 13 August 2020 / Accepted: 17 August 2020 / Published online: 24 August 2020

(C) W. Montague Cobb-NMA Health Institute 2020

\begin{abstract}
Background Data from the Survey of the Health of Urban Residents (SHUR) identified connections between police brutality and medical mistrust, generating significant media, policy, and research attention. Amidst intersecting crises of COVID-19, racism, and police brutality, this report describes survey development and data collection procedures for the SHUR.

Basic Procedures We conducted focus groups with Black men, Latinxs, and immigrants in Allentown, Pennsylvania. Findings were used to develop and refine measures of conditions salient to the health of urban residents across the country. Quota sampling was employed; oversampling people of color and persons whose usual source of care was not a doctor's office.

Main Findings Non-Hispanic Whites made up just under two thirds of the sample $(63.65 \%, n=2793)$. Black/African American respondents accounted for $14.2 \%$ of the sample $(n=623)$, while $11.62 \%(n=510)$ were Latinx. Only $43.46 \%$ of respondents reported a doctor's office as their usual source of care. Novel measures of population-specific stressors include a range of negative encounters with the police, frequency of these encounters, and respondents' assessments of whether the encounters were necessary. SHUR assessed the likelihood of calling the police if there is a problem, worries about incarceration, and cause-specific stressors such as race-related impression management.

Principal Conclusions SHUR $(n=4389)$ is a useful resource for researchers seeking to address the health implications of experiences not frequently measured by national health surveillance surveys. It includes respondents' zip codes, presenting the opportunity to connect these data with zip code-level health system, social and economic characteristics that shape health beyond individual factors.
\end{abstract}

Keywords SHUR data $\cdot$ Community-engaged health survey $\cdot$ Social conditions and health $\cdot$ Police brutality $\cdot$ Urban health

Sirry Alang

sma206@lehigh.edu

1 Department of Sociology and Program in Health Medicine and Society, Lehigh University, 31 Williams Drive \#280, Bethlehem, PA, USA

2 University of Minnesota School of Public Health, Minneapolis, MN, USA

3 Greater Newark Conservancy, Newark, NJ, USA

4 Promise Neighborhoods of the Lehigh Valley, Allentown, PA, USA

5 Lehigh Valley Health Network, Allentown, PA, USA

6 Neighborhood Health Centers of the Lehigh Valley, Allentown, PA, USA

7 Digestive Care, Inc., Bethlehem, PA, USA
One of several overarching goals of the Healthy People 2030 initiative is to create conditions that promote health and wellbeing for all [1]. These conditions include social, physical, and economic environments that enable people to stay healthy, and that are grounded in the fundamental principle of health equity. Healthy People 2030 also seeks to eliminate health disparities by addressing the structural drivers of inequities in health $[1,2]$. To achieve these goals, we must first identify the social determinants of health that are salient to the experiences of people who are socio-economically or racially marginalized. Social determinants of health are the conditions in which people are born, live, age, and work that shape a range of health outcomes including the likelihood of becoming sick, health status, and access to care [3]. COVID-19 has exposed how inequities in social, economic, and environmental conditions - social determinants - shape inequities in health outcomes [4]. Between health inequities made bare by 
COVID-19 and outrage over anti-Black racism and police brutality that followed the murder of George Floyd, understanding how structural racism shapes a range of social and economic conditions that impact the health outcomes of Black, Indigenous, and Latinx communities in the USA is critical.

Access to care matters for health outcomes [5-7]. However, given similar access, people who belong to racially marginalized groups and those who are experiencing poverty are less likely to initiate care $[8,9]$. Public hospitals, community health centers or clinics, and safetynet settings are defined by their shared vision to provide care to persons who need it regardless of their ability to pay [10]. As a result, these facilities are mostly used by people who are socio-economically disadvantagedmajority of whom belong to racial and ethnic minority groups, as well as undocumented persons and immigrants who might experience cost, cultural, language, and other barriers to care $[11,12]$. One very challenging issue in health disparities research is understanding why in urban areas with safety-net clinics, the prevalence of people with unmet need for health care is still high [13-15]. Mistrust in medical institutions is one cause of unmet need $[16,17]$.

A recent publication using data from the Survey of the Health of Urban Residents (SHUR) identified connections between experiences of police brutality and medical mistrust [18]. That publication continues to receive significant media, policy, and research attention, and researchers are interested in obtaining access to the data amidst intersecting crises of COVID-19, racism, and police brutality. In this brief report, we describe the process of developing the SHUR. The survey assesses experiences of police brutality, as well as a range of health, health care, social and economic characteristics, and experiences of people who live in urbanized areas in the USA based on the 2010 Census. These are areas with a population of at least 50,000 people. We hope that this report will facilitate dissemination and further analyses of the data to inform policies and programs needed for addressing health inequities.

\section{Methods}

Survey Development Conceptualization of the survey came from an ongoing partnership between academic researchers, a federally qualified health center (FQHC), and an equity-driven non-profit that serves as a hub for community leadership, empowerment, and transformation through social engagement. Our main project focused on exploring the experiences and dimensions of social exclusion and their effects on health outcomes. Academic partners analyzed the existing literature on social exclusion. The non-profit and FQHC partners organized three focus groups in Allentown, Pennsylvania: The first with Latinx populations, the second with Black men, and the third with immigrant populations. All partners trained community members who then facilitated the focus groups. For example, a Latino man was trained to facilitate the Latinx focus group. In these focus groups, we found that participants experienced specific salient stressors that shaped their health outcomes, conditions that were neither regularly captured in our population health surveillance surveys nor were in the broad literature on social determinants of health.

Using the data from focus groups, academic partners began developing a brief but comprehensive survey that includes these experiences. We worked with our nonprofit and $\mathrm{FQHC}$ partners in a process that involved multiple conversations with community members who have a broad range of expertise. They included religious leaders, teachers, students and interns, health care providers, previously incarcerated and justice-involved individuals, and people with multiple chronic conditions, including substance use disorders. University partners searched for any existing instruments consistent with the experiences of marginalized communities. Community members critiqued some of the existing instruments to ensure that word choices reflected their experiences and co-created new measures.

Measures Novel measures of stressors such as a range of negative encounters with the police and assessments of whether those encounters were necessary were included to assess experiences of police brutality. We conceptualize police brutality not merely as the use of force by a police officer, but police action that dehumanizes the victim, even without conscious intent $[19,20]$. Respondents were provided with the following examples of police actions: police cursed at respondent; police searched, frisked, or patted the respondent; police threatened to arrest the respondent; police handcuffed the respondent; police threatened the respondent with a ticket; police shoved or grabbed the respondent; police hit or kicked the respondent; police used pepper spray or another chemical on the respondent; police used an electroshock weapon such as a stun gun on the respondent, and police pointed a gun at the respondent. For each of these actions, respondents were asked whether it never happened to them, has happened about once or twice in their lives, happens a few times a year, about once a month, or happens about weekly. SHUR also assessed respondents' evaluations of the necessity of the police actions they had experienced. They were asked: "Thinking of your most recent experience(s) with the police, would you say the action of the 
officer was necessary?" Our focus group participants contend that individual perceptions of the necessity of police actions are important indicators of the dehumanizing impact of police violence.

We also assessed the likelihood of calling the police if there is a problem, worries about potential police brutality, arrest or incarceration, and cause-specific stressors such as race-related impression management, concerns about housing, food, and medical bills. We collected data on reasons for perceived discrimination such as race, language or accent, religion, immigration status, sexual orientation, and gender identity. We also assessed spaces and perpetrators of discrimination-whether discrimination was experienced at work, school, or perpetuated by a health care provider, police or security officer, or an individual in one's neighborhood. Other novel measures included in the survey are relational aspects of health care delivery, such as respondents' perceptions of respect during their clinical encounter, and specifically by receptionists, nurses, medical or nursing assistants, and physicians.

The survey included three indicators of respondents' sense of social exclusion, feeling like they are not trusted, often feeling left out, and not feeling like a member of a community. We also included existing measures of stressors such as discrimination using the Everyday Discrimination and the Heightened Racial Vigilance scales [21], Group-Based Medical Mistrust scale [22], and the Adverse Childhood Experiences (ACEs) module [23].

We included the following measures of health status: selfrated health, activity limitations (respondent limited in any way in any activities because of physical, mental, or emotional problems), self-rated mental health, and depression and anxiety using the two-item patient health questionnaire [24]. Indicators of access to care include usual source of care, health insurance, perceived unmet need for medical care, perceived unmet need for mental health care, past use of mental health services, and the probability of seeking mental health care. Sociodemographic data collected include race, gender identity, sexual orientation, age, marital status, level of education, work status, years in the USA if born outside of the USA, and zip code.

The survey instrument was pre-tested among a small subset of community members in Allentown $(n=11)$. Revisions were made, and the survey was then piloted using a convenient online sample $(n=100)$ with respondents from 65 zip codes across the country, majority being from the East Coast. The final version of the survey, after piloting, is presented in Appendix 1. Approval from Lehigh University's Institutional Review Board was obtained both for the initial social exclusion focus groups and for the survey. The focus groups and survey were funded internally by Lehigh University's Community- engaged Health Research Fellowship and the Faculty Innovation Grant, respectively.

\section{Data Collection}

The SHUR employed quota sampling, a non-probability sampling approach where we looked for specific characteristics of respondents and then obtained a tailored sample that is representative of the population of interest. The target was 4000 respondents living in urban areas in the contiguous USA. We assigned quotas for usual source of care and race/ethnicity. Black, Indigenous, and people color, as well as those who are poor, are more likely to receive care at specific sites rather than from a specific primary care physician with whom they have established a relationship [25]. Having a regular source of care, and the kind of place that people go to for usual care matters for relational aspects of care such as perceived respect and mistrust. Given this literature, we assigned a quota for usual source of care. At least half of the sample $(n=2000)$ must report a clinic or community health center, an emergency department or urgent care facility as their usual source of care, or report that they did not have a usual source of care.

The second quota was specific for race/ethnicity. Because we needed 4000 respondents, 1000 respondents (at least 25\%) must be people of color and no more than $65 \%$ should be nonHispanic White. This falls within the range of the US Census and Pew Center estimates of the racial demographics of urbanized areas and provides enough sample sizes to complete analysis by race/ethnicity. We contracted with Qualtrics because their panels are relatively more demographically representative than other online survey platforms for convenience sampling [26].

Qualtrics invited respondents by partnering with over 20 Web-based panel providers to access potential respondents based on the specified quotas. Respondents received some form of incentive from panel providers, but the specific value of the incentive was not disclosed to researchers. Qualtrics monitored the specified quotas using screening questions on race/ethnicity and usual source of care. For example, when enough non-Hispanic Whites had completed the survey, anyone who identified as non-Hispanic White who expressed interest in taking the survey was not redirected to the full survey. This process continued until the quotas were met. A total of 7495 persons passed the screeners and met the quota requirements. Qualtrics performed quality checks on the data and removed incomplete responses. They also assessed the time it took for respondents to complete the survey. The median time for survey completion was $10 \mathrm{~min}$. Respondents who took less than a third of the median time to complete the survey were excluded from the final sample because of the possibility that 
Table 1 Selected characteristics of SHUR respondents

\begin{tabular}{|c|c|c|c|}
\hline & Percent & Number & $\bar{x}$ (range) \\
\hline \multicolumn{4}{|l|}{ Race and ethnicity } \\
\hline Non-Hispanic White & 63.65 & 2793 & \\
\hline Non-Hispanic Black & 14.20 & 623 & \\
\hline Hispanic/Latinx & 11.62 & 510 & \\
\hline American Indian and Alaskan Native & 1.39 & 61 & \\
\hline Asian & 3.81 & 167 & \\
\hline Other/multiple & 5.33 & 234 & \\
\hline \multicolumn{4}{|l|}{ Gender identity } \\
\hline Cisgender man & 24.52 & 1076 & \\
\hline Cisgender woman & 70.84 & 3109 & \\
\hline Gender fluid & 3.08 & 135 & \\
\hline Transgender man & 0.84 & 37 & \\
\hline Transgender woman & 0.73 & 32 & \\
\hline \multicolumn{4}{|l|}{ Age category } \\
\hline $18-24$ & 19.25 & 845 & \\
\hline $25-34$ & 27.59 & 1211 & \\
\hline $35-44$ & 20.92 & 918 & \\
\hline $45-54$ & 13.69 & 601 & \\
\hline $55-64$ & 9.93 & 436 & \\
\hline 65 and older & 8.61 & 378 & \\
\hline \multicolumn{4}{|l|}{ Work status } \\
\hline Not in the labor force & 32.71 & 1390 & \\
\hline Unemployed, looking for work & 12.31 & 523 & \\
\hline Working for pay, part time $<30 \mathrm{~h} /$ week & 15.65 & 665 & \\
\hline Working for pay, full time $>=30 \mathrm{~h} /$ week & 39.34 & 1672 & \\
\hline \multicolumn{4}{|l|}{ Usual source of care } \\
\hline Community clinic/health center & 26.59 & 1167 & \\
\hline Doctor's office & 42.36 & 1859 & \\
\hline Emergency room & 11.37 & 499 & \\
\hline Outpatient department such as urgent care & 11.07 & 486 & \\
\hline No usual source of care & 7.97 & 350 & \\
\hline Some other place & 0.64 & 28 & \\
\hline Reports unmet need for medical care & 37.72 & 1639 & \\
\hline \multicolumn{4}{|l|}{ Often feels left out } \\
\hline Strongly disagree & 10.64 & 453 & \\
\hline Disagree & 18.06 & 769 & \\
\hline Agree nor disagree & 29.56 & 1259 & \\
\hline Agree & 15.45 & 658 & \\
\hline Strongly agree & 26.30 & 1120 & \\
\hline Has experienced racial discrimination & 14.42 & 633 & \\
\hline \multicolumn{4}{|c|}{ Consciously acts in ways to make sure you do not live up to racial stereotypes } \\
\hline Never & 34.04 & 1464 & \\
\hline Sometimes & 42.46 & 1826 & \\
\hline Always & 23.51 & 1011 & \\
\hline \multicolumn{4}{|l|}{ Worries about housing } \\
\hline Never & 31.67 & 1362 & \\
\hline Sometimes & 41.90 & 1802 & \\
\hline Always & 26.44 & 1137 & \\
\hline
\end{tabular}


Table 1 (continued)

\begin{tabular}{llll}
\hline & Percent & Number & $\bar{x}$ (range) \\
\hline Never & 41.32 & 1777 & \\
Sometimes & 39.55 & 1701 & \\
Always & 7.95 & 823 & \\
Worries someone they know will become a victim of police brutality & & \\
Never & 53.99 & 2322 & \\
Sometimes & 33.04 & 1421 & \\
Always & 12.97 & 558 & $29.19(12-60)$ \\
Has had a negative encounter with the police & 56.86 & 2495 & $7.03(2-10)$ \\
Mean medical mistrust score & & 4380 & \\
Mean overall respect rating & & 4318 & \\
\hline
\end{tabular}

they were not paying attention to the questions and might have been checking response boxes as quickly as possible. After these checks, we were left with 4389 completed responses.

\section{Survey Results}

We provide a brief description of the survey results by select characteristics in Table 1. As shown, non-Hispanic Whites make up just under two thirds of the sample (63.65\%, $n=2793)$. Black/African American respondents constitute $14.2 \%$ of the sample $(n=623)$, while $11.62 \%(n=510)$ are Hispanic/Latinx. SHUR respondents are disproportionately cisgender women $(70.85 \%, n=3109)$, and the majority are under the age of 65 ; only $8.61 \%(n=378)$ are 65 years of age or older. While slightly more than half of the respondents worked full-time or part-time, three in ten were not in the labor force, and about one in ten were in the labor force but were unemployed and looking for work at the time of the survey.

In terms of access to care and health services, most of the respondents had a usual source of care, but they were pretty spread out in terms of the specific places they regularly went to for care. For example, four in ten of the respondents received care from the doctor's office, two in ten at a community clinic, and one in ten at the emergency room. More than a third of the respondents reported unmet need for medical care $(37.72 \%, n=1639)$. Response options on the 12 -item groupbased medical mistrust index ranged from strongly disagree (1) to strongly agree (5). Scores on the medical mistrust scale ranged from 12 to 60 , with higher scores indicating greater mistrust of health institutions. The mean mistrust score for the sample was 29.19. Respondents rated if they felt, in general, that they were treated with a great deal of respect and dignity the last time they received healthcare. Ratings could range from 1 (no respect at all) to 10 (utmost respect). The range for our sample was 2 to 10 , with a mean of 7.03 , and a median of 9 .

Feeling left out is one indicator of social exclusion. About four in ten respondents agree or strongly agree that they often felt left out. Many respondents also reported experiencing salient sources of stress. For example, $14.42 \%$ of the sample $(n=633)$ felt hassled, inferior, or discriminated against because of race, accounting for more than half of the respondents who reported any kind of discrimination. Almost a quarter of the respondents engaged in race-related impression management-always careful to act in a way that did not consciously live up to the stereotypes of their racial and ethnic groups; $26.4 \%$ ( $n=1137)$ were always worried about being able to pay rent/mortgage/housing costs while $19.14 \%(n=823)$ always worried that they would not be able to pay their medical bills if they got sick or had an accident. Even though four in ten always or sometimes worried that someone they know would become a victim of police brutality, $56.86 \%(n=2495)$ reported having experienced at least one of the ten listed negative interactions with the police.

\section{Public Health Implications}

The SHUR is a great resource for researchers and policymakers interested in understanding and addressing factors relevant to the health of marginalized populations. Research published using SHUR data can contribute significantly to ongoing conversations around the connections between police brutality and health, especially access to care and medical mistrust [18]. Nevertheless, there are caveats. First, SHUR does not employ probability sampling. Therefore, estimates from the survey might be 
sensitive to systematic errors because respondents might differ from non-respondents in significant ways. Second, we did not assess respondents' perceptions of the necessity of each negative police encounter. Instead, we asked respondents to think about their most recent experiences with the police and to state their perceptions about whether the action(s) of the police were necessary. While we wanted to capture more recent exposures to police brutality, we think that perceptions about the necessity of negative police encounters might be different for different police actions. For example, an individual might perceive the police patting them down before an arrest as necessary and a previous encounter where the police kicked them as unnecessary. These actions have implications especially for assessing mental health correlates of police brutality such as anxiety and depression.

Despite these limitations, SHUR can support health disparities research in several ways. First, the survey is informed by the experiences of racialized populationsspecifically Black men, Latinxs, and immigrants - and assesses salient conditions including sources and spaces of discrimination, social exclusion, experiences of police brutality and stressful anticipations of these experiences, housing-related stress, as well as stress-related to arrests and incarceration. These data can help us identify connections between specific social determinants and a range of indicators of access to care and health status that are included in the data. These connections are important for formulating and implementing targeted policies to address health inequities.

Second, SHUR measures relational aspects of care such as mistrust and perceptions of respect that we know are important indicators of the delivery of patient-centered care $[27,28]$. When patients feel respected, they might then feel supported and empowered to share their own needs, perspectives, and preferences, and therefore engage in shared-decision making [29]. This might also equalize the inherent power differentials between clinicians and patients, regardless of race and socio-economic status. The data have the potential of helping researchers understand factors that shape relational aspects of care to improve engagement and reduce unmet need.

Third, SHUR includes respondents' zip codes. This presents researchers with the rare opportunity to link the data to zip code-level health system characteristics including the availability of physicians, housing characteristics, foreclosure rates, food insecurity, incarceration rates, voting and other indicators of political participation, as well as population-level indicators of structural racism such as Black to White ratios in rates of unemployment, poverty, health insurance, and college graduation. These larger structural factors, including structural racism, shape health beyond individual behaviors and attributes [30, 31]. Therefore, examining their interaction with individual factors in multi-level analyses is critical. In addition, researchers using these data can explore how variation in characteristics of urban areas, including population density, might be associated with variation in a range of experiences and health outcomes.

The approach employed in SHUR - co-creating measures of salient stressors with communities for which our work bears relevance is important for understanding the mechanisms through which social conditions affect health, the contextual specificity of these mechanisms, and what kinds of interventions might help eliminate health disparities caused by structural inequalities. Measures in the current survey are critical for providing evidence needed to inform policies that would improve health among urbanized populations. We encourage others to use these data. Community-driven approaches to creating measures related to navigating COVID-19 that are salient to the experiences of populations marginalized by structural inequalities are important next steps.

Acknowledgments The authors thank focus group participants, interpreters, and entire staff of Promise Neighborhoods of the Lehigh Valley for their work in organizing the focus groups.

Availability of Data and Material The data can be accessed by request to the corresponding author.

Authors' Contributions SA conceptualized the research project and lead in the development of the survey and the manuscript. CP and MM assisted in the review of instruments, survey data analysis, and writing. $\mathrm{HB}$ and $\mathrm{AB}$ were part of the conceptualization of study and assisted with focus group organization. $\mathrm{JH}, \mathrm{AS}$, and $\mathrm{KB}$ collected focus group data and assisted in identifying salient stressors and indicators of exclusion. KM assisted in the writing. All authors contributed significantly to this work. All authors take responsibility for the content of the manuscript.

Funding The focus groups and survey were funded by Lehigh University's Community-Engaged Health Research Fellowship and the Faculty Innovation Grant, respectively.

\section{Compliance with Ethical Standards}

Conflict of Interest The authors declare that they have no conflict of interests.

Ethics Approval Both the focus groups and survey received approval from Lehigh University's Institutional Review Board.

Consent to Participate All focus group participants and survey respondents freely consented to participate.

\section{Consent for Publication N/A}

Code Availability Stata codes can be accessed by request to the corresponding author. 


\section{Appendix}

\section{SURVEY OF THE HEALTH OF URBAN RESIDENTS}

1. What kind of place do you go to most often when you are sick or need advice about your health? (CHECK ONE ONLY)

$\square$ Clinic or health center

$\square$ Doctor's office

$\square$ Emergency room

- Hospital outpatient department such as urgent care

I I don't have a usual place that I go to

$\square$ Some other place (SPECIFY)

2. What race(s) do you consider yourself to be? (CHECK ALL THAT APPLY)

DAmerican Indian or Alaskan Native

DBlack

DWhite

$\square$ Asian

$\square$ Native Hawaiian or other Pacific Islander

$\square$ Some other race (SPECIFY)

3. During the past 12 months, would you say your physical health has been...? (CHECK ONE ONLY)

$\square$ Excellent
$\square$ Very Good
$\square$ Good
$\square$ Fair, or
$\square$ Poor

4. Think about the last time you received healthcare. On a scale from 1 to 10 , please rate how much you disagree or agree that you were treated with respect and dignity throughout the process. $(1=$ strongly disagree and $10=$ strongly agree $)$

5. Think about the last time you received healthcare. Would you say in general, you were treated with a great deal of respect and dignity, a fair amount, not too much, or none at all? (CHECK ONE ONLY)

$\square$ Great deal

$\square$ A fair amount

$\square$ Not too much

$\square$ None at all

6. Think about the last time you received healthcare. Would you say the receptionist or the person who checked you in treated you with a great deal of respect and dignity, a fair amount, not too much, or none at all? (CHECK ONE ONLY) 
$\square$ Great deal

$\square$ A fair amount

$\square$ Not too much

$\square$ None at all

7. Think about the last time you received healthcare. Would you say the nurses or the medical assistants treated you with a great deal of respect and dignity, a fair amount, not too much, or none at all? (CHECK ONE ONLY)

$\square$ Great deal

$\square$ A fair amount

$\square$ Not too much

$\square$ None at all

8. Think about the last time you received healthcare. Would you say the doctor treated you with a great deal of respect and dignity, a fair amount, not too much, or none at all? (CHECK ONE ONLY)

$\square$ Great deal

$\square$ A fair amount

$\square$ Not too much

$\square$ None at all

9. During the past 12 months, would you say your emotional or psychological health has been (CHECK ONE ONLY)

$\square$ Excellent

$\square$ Very Good

$\square$ Good

$\square$ Fair

$\square$ Poor

10. Over the past two weeks, how often have you been bothered by little interest or pleasure in doing things? (CHECK ONE ONLY)

$\square$ Not at all

$\square$ Several days

$\square$ More than half the days

$\square$ Nearly every day

11. Over the past two weeks, how often have you been bothered by feeling down, depressed, or hopeless? (CHECK ONE ONLY)

$\square$ Not at all

$\square$ Several days

$\square$ More than half the days

$\square$ Nearly every day

12. Which types of health insurance do you have? (SELECT ALL THAT APPLY)

$\square$ Medicare 
$\square$ Medicaid or insurance provided by your state.

$\square$ Military health care (TRICARE/VA/CHAMP-VA)

$\square$ Your employer's plan or a student plan

$\square$ Private, you pay for it by yourself

$\square$ No health insurance of any type

$\square$ You don't know

13. Was there a time in the past 12 months when you needed medical care but did not get it? Medical care includes doctor's visits, tests, procedures, prescription medication and hospitalizations.

$\square$ Yes

$\square \mathrm{No}$

14. Over the past two weeks, how often have you been bothered by feeling nervous, anxious or on edge? (CHECK ONE ONLY)

$\square \quad$ Not at all

$\square$ Several days

$\square$ More than half the day

$\square$ Nearly every day

15. Over the past two weeks, how often have you been bothered by not being able to stop or control worrying? (CHECK ONE ONLY)

$\square \quad$ Not at all

$\square$ Several days

$\square$ More than half the day

$\square$ Nearly every day

16. During the past 12 months, was there any time when you needed mental health treatment or counseling for yourself but did not get it?

$\square$ Yes

$\square$ No

17. Are you limited in any way in any activities because of physical, mental, or emotional problems?

$\square$ Yes

$\square$ No

18. If you thought you had an emotional problem such as depression, how likely is it that you would seek out treatment? (CHECK ONE ONLY)

$\square$ Very likely

$\square$ Somewhat likely

$\square$ Somewhat unlikely

口 Very unlikely 
19. Have you ever seen a mental health provider, such as a psychiatrist, psychologist, social worker, psychiatric nurse or counselor for an emotional or mental health problem? Please do not include visits for alcohol or drug use.

\section{$\square$ Yes \\ $\square$ No}

\section{People have different experiences and beliefs about the healthcare system. Based upon your experiences, how strongly do you disagree or agree with the following statements.}

a. Doctors and health care workers sometimes hide information from patients who belong to my racial or ethnic group.

$\square$ Strongly Disagree $\square$ Disagree $\square$ Neither Agree nor Disagree $\square$ Agree $\square$ Strongly Agree

b. Doctors have the best interests of people of my racial or ethnic group in mind.

$\square$ Strongly Disagree $\square$ Disagree $\square$ Neither Agree nor Disagree $\square$ Agree $\square$ Strongly Agree

c. People of my racial or ethnic group should not confide in doctors and health care workers because it will be used against them.

$\square$ Strongly Disagree $\square$ Disagree $\square$ Neither Agree nor Disagree $\square$ Agree $\square$ Strongly Agree

d. Healthcare organizations often want to know more about your business than they need to know.

$\square$ Strongly Disagree $\square$ Disagree $\square$ Neither Agree nor Disagree $\square$ Agree $\square$ Strongly Agree

e. People of my racial or ethnic group should not be suspicious of information from doctors and health care workers.

$\square$ Strongly Disagree $\square$ Disagree $\square$ Neither Agree nor Disagree $\square$ Agree $\square$ Strongly Agree

f. People of my racial or ethnic group should be suspicious of modern medicine.

$\square$ Strongly Disagree $\square$ Disagree $\square$ Neither Agree nor Disagree $\square$ Agree $\square$ Strongly Agree

g. Doctors and health care workers treat people of my racial and ethnic group like "guinea pigs."

$\square$ Strongly Disagree $\square$ Disagree $\square$ Neither Agree nor Disagree $\square$ Agree $\square$ Strongly Agree

h. People of my racial and ethnic group receive the same medical care from doctors and health care workers as people from other groups.

$\square$ Strongly Disagree $\square$ Disagree $\square$ Neither Agree nor Disagree $\square$ Agree $\square$ Strongly Agree

i. I have personally been treated poorly or unfairly by doctors or health care workers because of my race or ethnicity.

$\square$ Strongly Disagree $\square$ Disagree $\square$ Neither Agree nor Disagree $\square$ Agree $\square$ Strongly Agree

j. People of my racial and ethnic group are treated the same as people of other groups by doctors and health care workers.

$\square$ Strongly Disagree $\square$ Disagree $\square$ Neither Agree nor Disagree $\square$ Agree $\square$ Strongly Agree

k. Doctors and health care workers do not take the medical complaints of people of my racial and ethnic group seriously. 
$\square$ Strongly Disagree $\square$ Disagree $\square$ Neither Agree nor Disagree $\square$ Agree $\square$ Strongly Agree

1. In most hospitals, people of different racial or ethnic groups receive the same kind of care

$\square$ Strongly Disagree $\square$ Disagree $\square$ Neither Agree nor Disagree $\square$ Agree $\square$ Strongly Agree

\section{The next set of questions are about stresses that people might experience in life. Please} select whether the following statements were never true, sometimes true, or often true for you in the last 12 months.

21. Consciously conduct yourself in a manner that will not fulfil stereotypes about your racial or ethnic group.

$\square$ Never true

Sometimes true

$\square$ Often true

22. Worried that your food would run out before you get money to buy more.

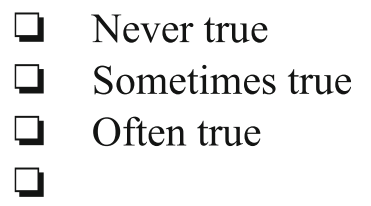

23. Worried about paying rent/mortgage/housing costs.

$\square$ Never true

$\square$ Sometimes true

$\square$ Often true

24. Worried that you may get arrested or incarcerated.
$\square \quad$ Never true
$\square$ Sometimes true
$\square$ Often true

25. Worried about paying medical bills because of an illness or accident.
$\square \quad$ Never true
$\square$ Sometimes true
$\square$ Often true

26. Worried that you will be a victim of police maltreatment or brutality
$\square$ Never true
- Sometimes true
$\square$ Often true

27. Worried someone close to you will be a victim of police brutality

$\square$ Never true

$\square$ Sometimes true 


\section{Often true}

28. How often have you personally had the following experiences with the police?

a) Cursed at you

$\square$ Never $\square$ About once or twice in my life $\square$ A few times a year $\square$ About once a month $\square$ About weekly

b) Searched, frisked or patted you down

$\square$ Never $\square$ About once or twice in my life $\square$ A few times a year $\square$ About once a month $\square$ About weekly

c) Threatened to arrest you

$\square$ Never $\square$ About once or twice in my life $\square$ A few times a year $\square$ About once a month $\square$ About weekly

d) Threatened you with a ticket or another ticket

$\square$ Never $\square$ About once or twice in my life $\square$ A few times a year $\square$ About once a month $\square$ About weekly

e) Actually pushed or grabbed you

$\square$ Never $\square$ About once or twice in my life $\square$ A few times a year $\square$ About once a month $\square$ About weekly

f) Handcuffed you

$\square$ Never $\square$ About once or twice in my life $\square$ A few times a year $\square$ About once a month $\square$ About weekly

g) Actually kicked or hit you

$\square$ Never $\square$ About once or twice in my life $\square$ A few times a year $\square$ About once a month $\square$ About weekly

h) Actually sprayed you with a chemical or pepper spray

$\square$ Never $\square$ About once or twice in my life $\square$ A few times a year $\square$ About once a month $\square$ About weekly

i) Actually used an electroshock weapon against you, such as a stun gun

$\square$ Never $\square$ About once or twice in my life $\square$ A few times a year $\square$ About once a month $\square$ About weekly

j) Actually pointed a gun at you

$\square$ Never $\square$ About once or twice in my life $\square$ A few times a year $\square$ About once a month $\square$ About weekly 
28. Thinking of your most recent experience(s) with the police, would you say the action of the officer was necessary?

$\square \quad$ Yes

$\square \quad$ No

29. If you had a problem, or witnessed a problem, how likely is it that you would contact or call the police for help?

$\square \quad$ Very likely

$\square \quad$ Somewhat likely

$\square \quad$ Somewhat unlikely

$\square \quad$ Very unlikely

30. We would like to ask you some questions about events that happened during your childhood. Looking back before you were 18 years of age,

a) Did you live with anyone who was depressed, mentally ill, or suicidal?

$\square \quad$ Yes

$\square \quad$ No

b) Did you live with anyone who was a problem drinker or alcoholic?

$\begin{array}{ll}\square & \text { Yes } \\ \square & \text { No }\end{array}$

c) Did you live with anyone who used illegal street drugs or who abused prescription medications?

$\square \quad$ Yes

$\square \quad$ No

d) Did you live with anyone who served time or was sentenced to serve time in a prison, jail, or other correctional facility?

$\square \quad$ Yes

$\square \quad$ No

e) Were your parents separated or divorced?

$\square \quad$ Yes

$\square \quad$ No

f) Did one or both of your parents die?

$\square \quad$ Yes

$\square \quad$ No 
g) How often did your parents or adults in your home ever slap, hit, kick, punch or beat each other up??

$\begin{array}{ll}\square & \text { Never } \\ \square & \text { Once } \\ \square & \text { More than once }\end{array}$

h) How often did your parents or adults in your home ever hit, beat, kick, or physically hurt you in any way? Do not include spanking.

Never

Once

More than once

i) How often did a parent or adult in your home ever swear at you, insult you, or put you down?

$\square \quad$ Never

$\square \quad$ Once

$\square \quad$ More than once

The next few questions are about your immediate neighborhood community. Please tell me how much you agree or disagree with the following statements.

31. I feel like people in my community do not trust me.

$\square$ Strongly Disagree $\square$ Disagree $\square$ Neither Agree nor Disagree $\square$ Agree $\square$ Strongly Agree

32. I feel that I am a member of my neighborhood community.

$\square$ Strongly Disagree $\square$ Disagree $\square$ Neither Agree nor Disagree $\square$ Agree $\square$ Strongly Agree

33. I often feel left out

$\square$ Strongly Disagree $\square$ Disagree $\square$ Neither Agree nor Disagree $\square$ Agree $\square$ Strongly Agree

34. Think about safety in your neighborhood. How safe would you say it is?

$\square \quad$ Very safe

$\square \quad$ Somewhat safe

$\square \quad$ Somewhat unsafe

$\square \quad$ Very unsafe

Thinking about the ways you have been treated in your city

35. Have you ever felt you were hassled, made to feel inferior, or discriminated against for any reason?

$\square \quad \mathrm{No}$

$\square$ Yes 
36. $A S K$ if $24=$ Yes.

At which of the following places or by which of the following institutions were you made to feel hassled, inferior, or discriminated against? (SELECT ALL THAT APPLY)

$\square$ The hospital, doctor's office, clinic or other healthcare provider

$\square$ The police, security or other law enforcement

$\square$ Other community members in your neighborhood.

$\square$ At work or in school

37. ASK if hassled, made to feel inferior or discriminated against at the hospital, doctor's office, clinic or health care provider

What was the reason or reasons you felt hassled, inferior, or discriminated against at the hospital, doctor's office, clinic or health care provider? (CHECK ALL THAT APPLY)

$\square$ Race, ethnicity, or skin color

$\square \quad$ Language or accent

$\square \quad$ Immigration status

$\square$ Sexual orientation

$\square$ Gender identity

$\square$ Sex

$\square \quad$ Some other reason ( SPECIFY)

38. ASK if hassled, made to feel inferior or discriminated against by the police, security or other law enforcement.

What was the reason or reasons you felt hassled, inferior, or discriminated against by the police, security or other law enforcement? (CHECK ALL THAT APPLY)

$\square$ Race, ethnicity, or skin color

$\square \quad$ Language or accent

$\square \quad$ Immigration status

$\square$ Sexual orientation

$\square$ Gender identity

$\square$ Sex

$\square$ Some other reason ( SPECIFY)

39. ASK if hassled, made to feel inferior or discriminated against by other community members in your neighborhood.

What was the reason or reasons you felt hassled, inferior, or discriminated against by other community members in your neighborhood? (CHECK ALL THAT APPLY)

$\square$ Race, ethnicity, or skin color

$\square \quad$ Language or accent

$\square \quad$ Immigration status

$\square \quad$ Sexual orientation 


\section{$\square \quad$ Gender identity \\ $\square$ Sex \\ $\square \quad$ Some other reason ( SPECIFY)}

40. ASK if hassled, made to feel inferior or discriminated against at work or in school. What was the reason or reasons you felt hassled, inferior, or discriminated against at work or in school? (CHECK ALL THAT APPLY)

$\square$ Race, ethnicity, or skin color

$\square \quad$ Language or accent

$\square \quad$ Immigration status

$\square$ Sexual orientation

$\square$ Gender identity

$\square$ Sex

$\square \quad$ Some other reason ( SPECIFY)

41. In your day-to-day life, how often do any of the following things happen to you?

a) You are treated with less courtesy or respect than other people.

$\square \quad$ Almost everyday

$\square \quad$ At least once a week

$\square \quad$ A few times a month

$\square \quad$ A few times a year

$\square \quad$ Less than once a year

$\square \quad$ Never

b) You receive poorer service than other people at restaurants or stores..

$\square \quad$ Almost everyday

$\square \quad$ At least once a week

$\square \quad$ A few times a month

$\square \quad$ A few times a year

$\square \quad$ Less than once a year

$\square \quad$ Never

c) People act as if they think you are not smart.
$\square \quad$ Almost everyday
$\square \quad$ At least once a week
$\square \quad$ A few times a month
$\square \quad$ A few times a year
$\square \quad$ Less than once a year
$\square \quad$ Never 
d) People act as if they are afraid of you.
$\square \quad$ Almost everyday
$\square \quad$ At least once a week
$\square \quad$ A few times a month
$\square \quad$ A few times a year
$\square \quad$ Less than once a year
$\square \quad$ Never

e) You are threatened or harassed.
$\square \quad$ Almost everyday
$\square \quad$ At least once a week
$\square \quad$ A few times a month
$\square \quad$ A few times a year
$\square \quad$ Less than once a year
$\square \quad$ Never

42. In your day-to-day life, how often do any of the following things happen to you?

a) You try to prepare for possible insults from other people before leaving home.
$\square \quad$ Almost everyday
$\square \quad$ At least once a week
$\square \quad$ A few times a month
$\square \quad$ A few times a year
$\square \quad$ Less than once a year
$\square \quad$ Never

b) Feel that you always have to be very careful about your appearance (to get good service or avoid being harassed).

$\begin{array}{ll}\square & \text { Almost everyday } \\ \square & \text { At least once a week } \\ \square & \text { A few times a month } \\ \square & \text { A few times a year } \\ \square & \text { Less than once a year } \\ \square & \text { Never }\end{array}$

c) Carefully watch what you say and how you say it.
$\square \quad$ Almost everyday
$\square \quad$ At least once a week 
$\square \quad$ A few times a month

$\square \quad$ A few times a year

$\square \quad$ Less than once a year

$\square \quad$ Never

d) Try to avoid certain social situations and places

$\begin{array}{ll}\square & \text { Almost everyday } \\ \square & \text { At least once a week } \\ \square & \text { A few times a month } \\ \square & \text { A few times a year } \\ \square & \text { Less than once a year } \\ \square & \text { Never }\end{array}$

Please enter your zip code

Finally, please answer some general questions about yourself. These questions will help us to interpret the results in the context of your community and city.

43. Please enter your zip code

44. What age group are you in?
$\square \quad 18-25$
26-35
36- 45
$46-55$
$\square \quad 56-65$
$\square \quad 65$ and older

45. What is your marital status?

$\square$ Currently married

$\square$ Not legally married but living in a marriage-like relationship

$\square$ Widowed

$\square$ Divorced or Separated

$\square$ Single

46. Please tell us if you are a member of you a member of any of the following ethnic or cultural groups?

$\square$ Latino or Hispanic

$\square$ Arab

$\square$ Neither 
47. Which of the following best represents how you think of yourself? (CHECK ONE ONLY)

$\square$ Gay

$\square$ Straight, that is, not gay

$\square$ Bisexual

$\square$ Other (SPECIFY)

48. Are you currently...? (CHECK ONE ONLY)

$\square$ Working full-time for pay (35 or more hours a week)

$\square$ Working part-time for pay

$\square$ Unemployed, looking for work

$\square$ Not in the labor force, because you are retired, disabled, in school, or a homemaker

49. What is the highest grade or level of school you have completed? (CHECK ONE

ONLY)

$\square$ Did not attend high school

$\square$ Some high school, did not graduate

$\square$ High school graduate or GED

$\square$ Technical or vocational school

$\square$ Some college or associate degree

$\square$ Four year college degree (Bachelor's)

$\square$ Graduate or professional degree

$\square$

50. Were you born in the United States?

$\square$ Yes

$\square$ No

51. ASK IF $38=$ No

How long have you lived in the United States?

0-99 years (drop down)

52. What is your gender identity?
$\square$ Man
$\square$ Woman
$\square$ Transgender man
$\square$ Transgender women
$\square$ Gender fluid
$\square$ Other (SPECIFY) 


\section{References}

1. Office of Disease Prevention and Health Promotion. Healthy People 2030 framework. 2020. https://www.Healthypeople.Gov/ 2020/About-Healthy-People/Development-Healthy-People-2030/ Framework. Accessed 11 Aug 2020.

2. Johnson S, Gold MR, Baciu A. Rethinking the leading health indicators for healthy people 2030. In: JAMA health forum. 2020. p. E200426-E200426.

3. Office of Disease Prevention and Health Promotion. Social determinants of health $\mid$ healthy people 2020 . Healthy people 2020 topics and objectives 2015.

4. Van Dorn A, Cooney RE, Sabin ML. COVID-19 exacerbating inequalities in the US. Lancet (London, England). 2020;395:1243.

5. Andersen RM, Davidson PL, Baumeister SE. Improving access to care. Chang US Heal Care Syst Key Issues Heal Serv Policy Manag. 2013:33-69.

6. Henning-Smith C, Alang S. Access to care for children with emotional/behavioral difficulties. J Child Heal Care. 2014;20: 185-94.

7. Sommers BD, Gunja MZ, Finegold K, Musco T. Changes in selfreported insurance coverage, access to care, and health under the Affordable Care Act. JAMA. 2015;314:366-74.

8. Angier H, Hoopes M, Marino M, Huguet N, Jacobs EA, Heintzman $\mathrm{J}$, et al. Uninsured primary care visit disparities under the Affordable Care Act. Ann Fam Med. 2017;15:434-42.

9. Williams DR, Jackson PB. Social sources of racial disparities in health. Health Aff (Millwood). 2005;24:325-34.

10. Redlener I, Grant R. America's safety net and health care reformwhat lies ahead? N Engl J Med. 2009;361:2201-4.

11. Nathenson RA, Saloner B, Richards MR, Rhodes KV. Spanishspeaking immigrants' access to safety net providers and translation services across traditional and emerging US destinations. Milbank Q. 2016;94:768-99.

12. Nguyen OK, Makam AN, Halm EA. National use of safety-net clinics for primary care among adults with non-Medicaid Insurance in the United States. PLoS One. 2016;11:E0151610.

13. August EM, Steinmetz E, Gavin L, Rivera MI, Pazol K, Moskosky $\mathrm{S}$, et al. Projecting the unmet need and costs for contraception services after the Affordable Care Act. Am J Public Health. 2016;106:334-41.

14. Johnson TL, Rinehart DJ, Durfee J, Brewer D, Batal H, Blum J, et al. For many patients who use large amounts of health care services, the need is intense yet temporary. Health Aff. 2015;34: 1312-9.

15. Kertesz SG, Mcneil W, Cash JJ, Desmond R, Mcgwin G, Kelly J, et al. Unmet need for medical care and safety net accessibility among Birmingham's homeless. J Urban Heal. 2014;91:33-45.
16. Laveist TA, Isaac LA, Williams KP. Mistrust of health care organizations is associated with underutilization of health services. Health Serv Res. 2009;44:2093-105.

17. Mechanic D. The functions and limitations of trust in the provision of medical care. J Health Polit Policy Law. 1998;23:661-86.

18. Alang S, Mcalpine DD, Hardeman R. Police brutality and mistrust in medical institutions. J Racial Ethn Heal Disparities. 2020;7:760 8.

19. Alang S, Mcalpine D, Mccreedy E, Hardeman R. Police brutality and black health: setting the agenda for Public health scholars. Am J Public Health. 2017;107:662-5.

20. Bandes S. Patterns of injustice: police brutality in the courts. Bufflrev. 1999;47:1275.

21. Williams DR. Measuring discrimination resource. 2016.

22. Shelton RC, Winkel G, Davis SN, Roberts N, Valdimarsdottir H, Hall SJ, et al. Validation of the group-based medical mistrust scale among urban black men. J Gen Intern Med. 2010;25:549-55.

23. Finkelhor D. Screening for adverse childhood experiences (Aces): cautions and suggestions. Child Abuse Negl. 2018;85:174-9.

24. Kroenke K, Spitzer RL, Williams JBW, Löwe B. The patient health questionnaire somatic, anxiety, and depressive symptom scales: a systematic review. Gen Hosp Psychiatry. 2010;32:345-59.

25. Hing E, Hooker RS. Community health centers: providers, patients, and content of care. Age. 2011;45:18-44.

26. Boas TC, Christenson DP, Glick DM. Recruiting large online samples in the United States and India: Facebook, Mechanical Turk, and Qualtrics. Polit Sci Res Methods. 2018:1-19.

27. Flickinger TE, Saha S, Roter D, Korthuis PT, Sharp V, Cohn J, et al. Respecting patients is associated with more patient-centered communication behaviors in clinical encounters. Patient Educ Couns. 2016;99:250-5.

28. Fiscella K, Meldrum S, Franks P, Shields CG, Duberstein P, Mcdaniel SH, et al. Patient trust: is it related to patient-centered behavior of primary care physicians? Med Care. 2004;42:1049-55.

29. Mcleod H. Respect and shared decision making in the clinical encounter, a video-reflexive ethnography. 2017. Doctoral dissertation, University of Minnesota, Minneapolis.

30. Bailey ZD, Krieger N, Agénor M, Graves J, Linos N, Bassett MT. Structural racism and health inequities in the USA: evidence and interventions. Lancet. 2017;389:1453-63.

31. Diez Roux AV. Investigating neighborhood and area effects on health. Am J Public Health. 2001;91:1783-9.

Publisher's Note Springer Nature remains neutral with regard to jurisdictional claims in published maps and institutional affiliations. 